\title{
Abnormal differentiation of stem cells into enteroendocrine cells in rats with DSS-induced colitis
}

\author{
MAGDY EL-SALHY ${ }^{1-3}$, KAZUO UMEZAWA $^{4}$, JAN GUNNAR HATLEBAKK $^{2,3}$ and ODD HELGE GILJA ${ }^{2,3}$ \\ ${ }^{1}$ Division of Gastroenterology, Department of Medicine, Stord Hospital, 5409 Stord; \\ ${ }^{2}$ Division of Gastroenterology, Department of Clinical Medicine, University of Bergen, 5007 Bergen; ${ }^{3}$ National Centre for \\ Functional Gastrointestinal Disorders, Department of Medicine, Haukeland University Hospital, 5021 Bergen, Norway; \\ ${ }^{4}$ Department of Molecular Target Medicine, Aichi Medical University, School of Medicine, Nagakute, Aichi 480-1195, Japan
}

Received August 20, 2016; Accepted December 5, 2016

DOI: $10.3892 / \mathrm{mmr} .2017 .6266$

\begin{abstract}
The present study aimed to determine whether there is an association between abnormalities in enteroendocrine cells in dextran sulfate sodium (DSS)-induced colitis and the clonogenic and/or proliferative activities of stem cells. A total of 48 male Wistar rats were divided into four groups. Animals in the control group were provided with normal drinking water, whereas DSS colitis was induced in the remaining three groups. The rats with DSS-induced colitis were randomized into the following three groups: i) DSS group, which received $0.5 \mathrm{ml} 0.5 \%$ carboxymethyl cellulose (CMC; vehicle); ii) DSS-G group, which was treated with 3 -[(dodecylthiocarbonyl)-methyl]-glutarimide at $20 \mathrm{mg} / \mathrm{kg}$ body weight in $0.5 \% \mathrm{CMC}$; and iii) DSS-Q group, which was treated with dehydroxymethylepoxyquinomicin at $15 \mathrm{mg} / \mathrm{kg}$ body weight in $0.5 \% \mathrm{CMC}$. Treatments were administered intraperitoneally twice daily for 5 days in all groups. Subsequently, tissue samples from the colon were stained with hematoxylin-eosin, or immunostained for chromogranin A (CgA), Musashi 1 (Msi1), Math-1, neurogenin 3 (Neurog3) and neurogenic differentiation D1 (NeuroD1). The densities of CgA, Msi1-, Math-1-, Neurog3- and NeuroD1-immunoreactive cells were determined. DTCM-G, and DHMEQ ameliorated the inflammation in DSS-induced colitis. The density of CgA-, Neurog3- and NeuroD1-immunoreactive cells was significantly higher in the DSS group compared with in the control group, and the density of $\mathrm{CgA}$ cells was correlated with the densities of Neurog3- and NeuroD1-immunoreactive cells. There were no significant differences in the densities of Msi1and Math-1-immunoreactive cells among the four experimental groups. The elevated densities of enteroendocrine cells
\end{abstract}

Correspondence to: Professor Magdy El-Salhy, Division of Gastroenterology, Department of Medicine, Stord Hospital, PO Box 4000, 5409 Stord, Norway

E-mail: magdy.el-salhy@helse-fonna.no

Key words: chromogranin A, DSS-induced colitis, enteroendocrine cells, Math-1, Musashi 1, NeuroD1, stem cells detected in DSS-induced colitis may be due to the increased differentiation of early enteroendocrine progenitors during secretory lineage. It is probable that the DSS-induced inflammatory processes trigger certain signaling pathways, which control differentiation of the stem-cell secretory lineage into mature enteroendocrine cells.

\section{Introduction}

Inflammatory bowel disease (IBD) is a chronic disease that consists of ulcerative colitis (UC) and Crohn's disease (1-4). The clinical course of IBD varies markedly, from frequent relapses, to chronic active disease, to years of complete remission (5). At present, the etiology of IBD is not completely understood (6-8). There are at least five distinct types of enteroendocrine cell in the large intestine, which are arranged between the epithelial cells lining the intestinal lumen $(9,10)$. These cells regulate intestinal motility, secretion and absorption, as well as visceral sensitivity, local immune defense, cell proliferation and appetite $(9,11-26)$. The enteroendocrine cells in the large intestine are abnormal in patients with IBD and in animal models of IBD (24,27-42). Interactions between the hormones secreted by the large intestine enteroendocrine cells and the immune system have previously been debated, and it has been speculated that these interactions serve a critical role in the pathophysiology of IBD (43-45).

The cause of abnormalities in the large intestine enteroendocrine cells in IBD is not currently known. Abnormal intestinal enteroendocrine cells have been reported in congenital malabsorptive diarrhea alongside mutated transcription factor Neurogenin 3 (Neurog3), and in mutant mice with ablation of Neurog3 (46). The present study aimed to investigate whether the abnormalities observed in intestinal enteroendocrine cells in dextran sulfate sodium (DSS)-induced colitis are associated with abnormalities in the clonogenic and/or proliferative activities of stem cells (47). Furthermore, it was investigated whether the alterations in enteroendocrine cells and stem cells may be restored by treatment with two anti-inflammatory agents: 3-[(dodecylthiocarbonyl)-methyl]-glutarimide (DTCM-G) and dehydroxymethylepoxyquinomicin (DHMEQ). These agents have been demonstrated to exert potent anti-inflammatory activity in animal models $(48,49)$. 


\section{Materials and methods}

Rats. A total of 48 male Wistar rats (6 weeks old; Hannover GALAS; Taconic Europe A/S, Lille Skensved, Denmark) with a mean body weight of $290 \mathrm{~g}$ (range, 238-385 g) were housed in Macrolon III cages with ad libitum access to food and water. The rats were fed a standard diet (B\&K Universal Limited, Hull, UK), and were maintained under the following conditions: Temperature between 20 and $22^{\circ} \mathrm{C}$, relative humidity between 50 and $60 \%$, and 12/12-h light/dark cycle.

The animals were allowed to acclimate in the animal house for $\geq 1$ week prior to experimentation, and were then divided into 4 groups, each containing 12 rats. Rats in the control group were provided with normal drinking water for 7 days, whereas colitis was induced in the other three groups using DSS, as previously described $(50,51)$. Briefly, the rats were provided with distilled drinking water containing 5\% DSS (40 kD; TDB Consultancy AB, Uppsala, Sweden) for 7 days. The rats with DSS-induced colitis were randomized into the following three groups: i) DSS group, which received $0.5 \mathrm{ml} 0.5 \%$ carboxymethyl cellulose (CMC; vehicle); ii) DSS-G group, which was treated with DTCM-G at $20 \mathrm{mg} / \mathrm{kg}$ body weight in $0.5 \% \mathrm{CMC}$; and iii) DSS-Q group, which was treated with DHMEQ at $15 \mathrm{mg} / \mathrm{kg}$ body weight in $0.5 \% \mathrm{CMC}$. Treatments were administered intraperitoneally twice daily for 5 days in all groups. DTCM-G and DHMEQ were synthesized as described previously (52-55). The rats were monitored frequently, and those that showed any signs of pain were injected subcutaneously with $1 \mathrm{ml}$ Temgesic solution (containing $0.3 \mathrm{~g} / \mathrm{ml}$ Temgesic; Merck \& Co., Inc., Kenilworth, NJ, USA) as an analgesic.

At the end of the 5-day treatment period, rats were sacrificed by $\mathrm{CO}_{2}$ inhalation, the colon was collected, and tissue samples were obtained from the lower part of the colon for subsequent examinations. The present study was approved by the local ethical committee at the University of Bergen for the Protection of Vertebrate Animals used for Experimental and Other Scientific Purposes (Bergen, Norway; project no. 20124629).

Histopathology and immunohistochemistry. The tissue samples were fixed in $4 \%$ buffered paraformaldehyde, embedded in paraffin, and cut into $5 \mathrm{~mm}$ sections. The sections were stained with hematoxylin and eosin, or immunostained using the ultraView Universal DAB Detection kit (version 1.02.0018; Ventana Medical Systems, Inc., Tucson, AZ, USA) and the BenchMark Ultra IHC/ISH staining module (Ventana Medical Systems, Inc.). The sections were incubated with the following primary antibodies for $32 \mathrm{~min}$ at $37^{\circ} \mathrm{C}$ : Monoclonal mouse anti-N-terminal of purified chromogranin A (CgA; 1:1,500; cat. no. M869; Dako Denmark A/S, Glostrup, Denmark); polyclonal rabbit anti-residues 5-21 [APQPGLASPDSPHDPCK] of the human, mouse and rat Musashi 1 (Msi1) protein (1:100; cat. no. NB100-1759; R\&D Systems Europe, Abingdon, UK); polyclonal rabbit anti-synthetic peptide surrounding amino acid 190 of human Math-1 (1:50; code no. 3658-100; BioVision, Inc., Milpitas, CA, USA); polyclonal rabbit anti-KLH-conjugated synthetic peptide between 40-69 amino acids from the N-terminal region of human Neurog3 (1:50; cat. no. PA5-11893, Thermo Fisher, Oslo, Norway); and polyclonal rabbit anti-recombinant full-length human neurogenic differentiation D1 (NeuroD1; 1:50; cat. no. PA5-47381; Thermo Fisher). All of these antibodies detect antigens in humans and rats.

Quantification. The number of CgA-, Msi1-, Math-1-, Neurog3- and NeuroD1-immunoreactive cells, the number of crypts, and the area containing epithelial cells were counted in ten randomly selected microscopic fields using a light microscope (BX 43). Measurements were performed using cellSens imaging software (version 1.7; Olympus Corporation, Tokyo, Japan). This morphometric method has previously been validated (56). The number of immunoreactive cells and crypts in each field were counted manually by pointing and clicking the computer mouse, whereas the area of epithelial cells was determined by manual drawing using the computer mouse. A $\mathrm{x} 40$ objective was used, for which each frame (field) on the monitor represented a tissue area of $0.035 \mathrm{~mm}^{2}$. The density of $\mathrm{CgA}$ was expressed as the number of immunoreactive endocrine cells per square millimeter of epithelium, the density of Msi1 was expressed as the number of immunoreactive cells per crypt, and the densities of Math-1, Neurog3 and NeuroD1 were expressed as the number of immunoreactive cells per field. Immunostained sections were coded, and measurements were performed by the same individual (M.E-S.), who was blinded to the identity of the sections.

Statistical analysis. The Kruskal-Wallis nonparametric test and Dunn's post hoc test were used to compare between the control, DSS, DSS-G and DSS-Q groups. Correlations between abnormalities/alterations in the densities of $\mathrm{CgA}-$, Neurog3-, and NeuroD1-immunoreactive cells were determined using the nonparametric Spearman correlation test. Data are presented as the mean \pm standard error of the mean. $\mathrm{P}<0.05$ was considered to indicate a statistically significant difference.

\section{Results}

The colon samples collected from rats in the control, DSS-G and DSS-Q groups appeared histopathologically normal; however, in the DSS group, disturbed mucosal architecture, crypt abscesses, edema, bleeding and immune cell infiltration were observed (Fig. 1).

CgA immunostaining. CgA-immunoreactive cells were detected in crypts and alongside the gland of Lieberkühn. The cell densities in the control, DSS, DSS-G and DSS-Q groups were $113.0 \pm 20.4,319.1 \pm 32.0,123.9 \pm 22.6$ and $141.3 \pm 14.3$ cells $/ \mathrm{mm}^{2}$ epithelium, respectively (Kruskal-Wallis test, $\mathrm{P}<0.0001$; Figs. 2 and 3). Dunn's test indicated that the density of CgA-immunoreactive cells was significantly higher in the DSS group compared with in the control group $(\mathrm{P}<0.0001)$. The densities of CgA in DSS-G and DSS-Q did not differ from that of controls ( $\mathrm{P}=0.9$, and 0.1 , respectively). The CgA-immunoreactive cell density was correlated with the densities of Neurog3- and NeuroD1-immunoreactive cells $(\mathrm{r}=0.8 ; \mathrm{P}=0.006$ for both).

Msi1 immunostaining. Msi1-immunoreactive cells were observed exclusively in the crypts of the gland of Lieberkühn. 
A

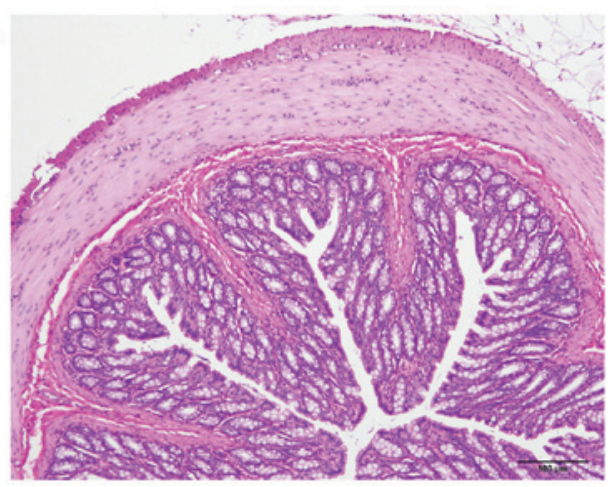

C

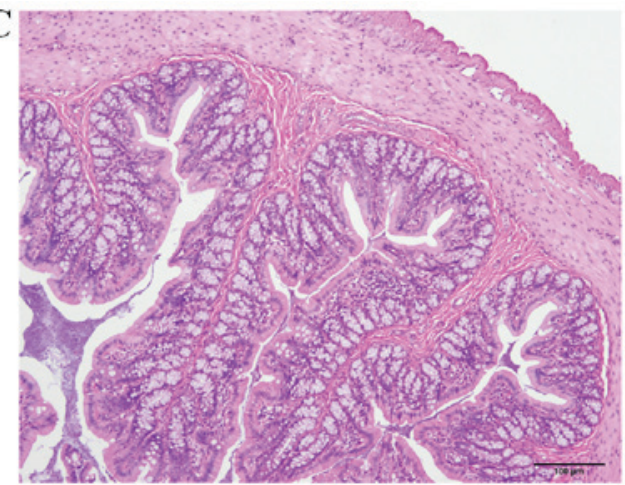

B

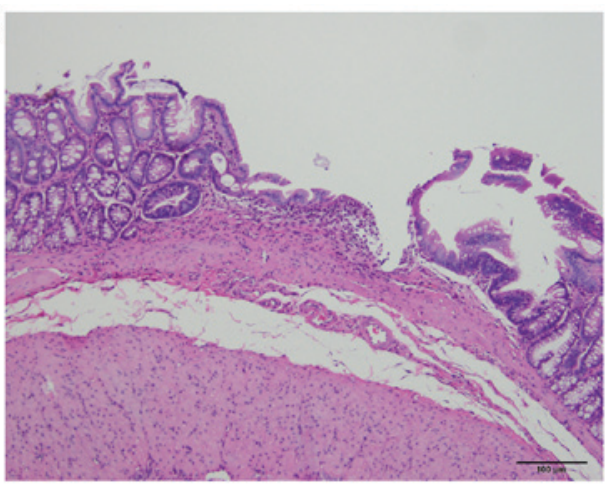

D

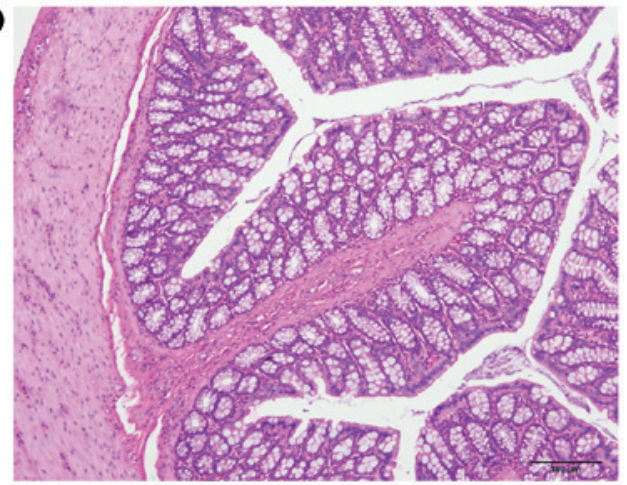

Figure 1. Histopathological staining with hematoxylin-eosin of (A) a control rat, and in rats from the (B) DSS, (C) DSS-G and (D) DSS-Q groups. DSS, dextran sulfate sodium-induced colitis vehicle-treated group; DSS-G, 3-[(dodecylthiocarbonyl)-methyl]-glutarimide-treated DSS group; DSS-Q, dehydroxymethylepoxyquinomicin-treated DSS group.

The cell densities in the control, DSS, DSS-G and DSS-Q groups were $4.9 \pm 0.5,4.8 \pm 0.5,5.1 \pm 0.6$ and $5.0 \pm 0.6$ cells/crypt, respectively (Kruskal-Wallis test, $\mathrm{P}=0.98$; Fig. 4).

Math-1 immunostaining. Math-1-immunoreactive cells were observed in the crypts and alongside the gland of Lieberkühn. The cell densities in the control, DSS, DSS-G and DSS-Q groups were $80.2 \pm 10.4,101.6 \pm 10.7,99.1 \pm 8.3$ and $100.1 \pm 11.3$ cells/field, respectively (Kruskal-Wallis test, $\mathrm{P}=0.41$; Fig. 4).

Neurog3 immunostaining. Neurog3-immunoreactive cells were detected in the crypts and alongside the gland of Lieberkühn (Figs. 4 and 5). The cell densities were 79.1 \pm 11.1 , $223.1 \pm 36.0,103.8 \pm 12.4$ and $77.3 \pm 10.9$ cells/field in the control, DSS, DSS-G and DSS-Q groups, respectively (Kruskal-Wallis test, $\mathrm{P}=0.002$ ). The Neurog3-immunoreactive cell density was significantly higher in the DSS group compared with in the control group (Dunn's test: $\mathrm{P}=0.0002$; Fig. $4 \mathrm{C}$ ). There was no statistically significant difference between controls and DSS-G and DSS-Q regarding Neurog 3 cell density ( $\mathrm{P}=0.1$, and 0.7 , respectively).

NeuroD1 immunostaining. Similar to Neurog3, NeuroD1immunoreactive cells were observed in the crypts and alongside the gland of Lieberkühn. The cell densities were $73.3 \pm 10.7$, $217.3 \pm 24.4,105.8 \pm 11.8$ and $79.1 \pm 10.7$ cells/field in the control, DSS, DSS-G and DSS-Q groups, respectively (Kruskal-Wallis test, $\mathrm{P}=0.0001$ ). The density of NeuroD1-immunoreactive cells was significantly higher in the DSS group compared with in

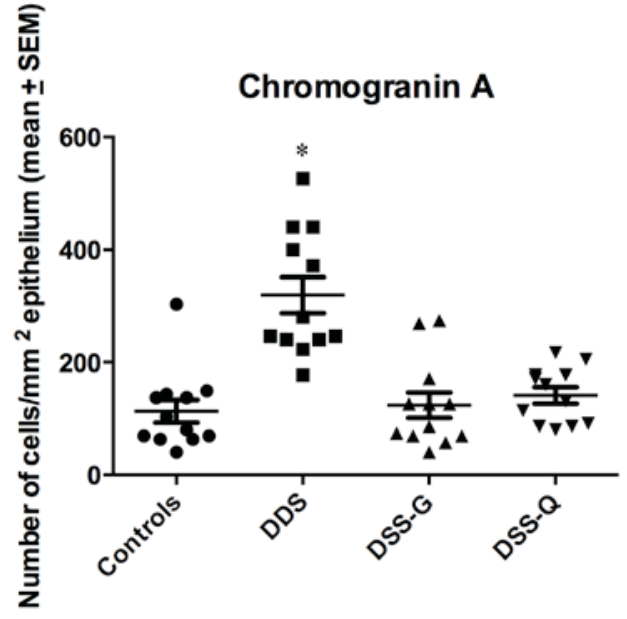

Figure 2. CgA-immunoreactive cell density in the control, DSS, DSS-G and DSS-Q groups. ${ }^{*} \mathrm{P}<0.0001$. DSS, dextran sulfate sodium-induced colitis vehicle-treated group; DSS-G, 3-[(dodecylthiocarbonyl)-methyl]-glutarimi de-treated DSS group; DSS-Q, dehydroxymethylepoxyquinomicin-treated DSS group; CgA, chromogranin A.

the control group (Dunn's test, $\mathrm{P}=0.0002$; Fig. 4). The densities of NeuroD1 in DSS-G, and DSS-Q did not differ from that of controls $(\mathrm{P}=0.07$, and 0.9 , respectively).

\section{Discussion}

$\mathrm{CgA}$ is a general marker for enteroendocrine cells (57). In the present study, the density of $\mathrm{CgA}$-immunoreactive cells 

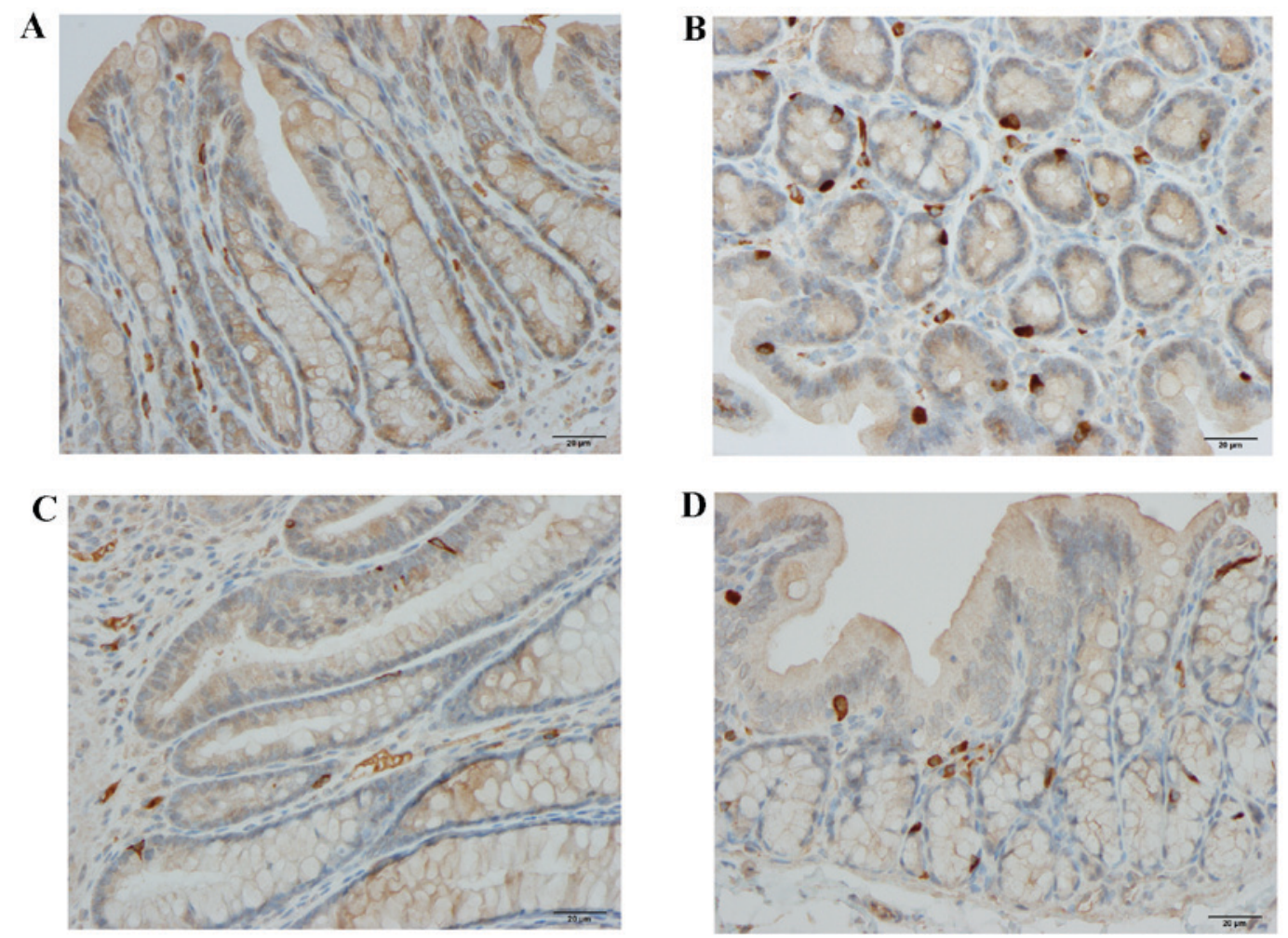

Figure 3. Colonic chromogranin A-immunoreactive cells in (A) a control rat, and in rats from the (B) DSS, (C) DSS-G and (D) DSS-Q groups. DSS, dextran sulfate sodium-induced colitis vehicle-treated group; DSS-G, 3-[(dodecylthiocarbonyl)-methyl]-glutarimide-treated DSS group; DSS-Q, dehydroxymethylepoxyquinomicin-treated DSS group.
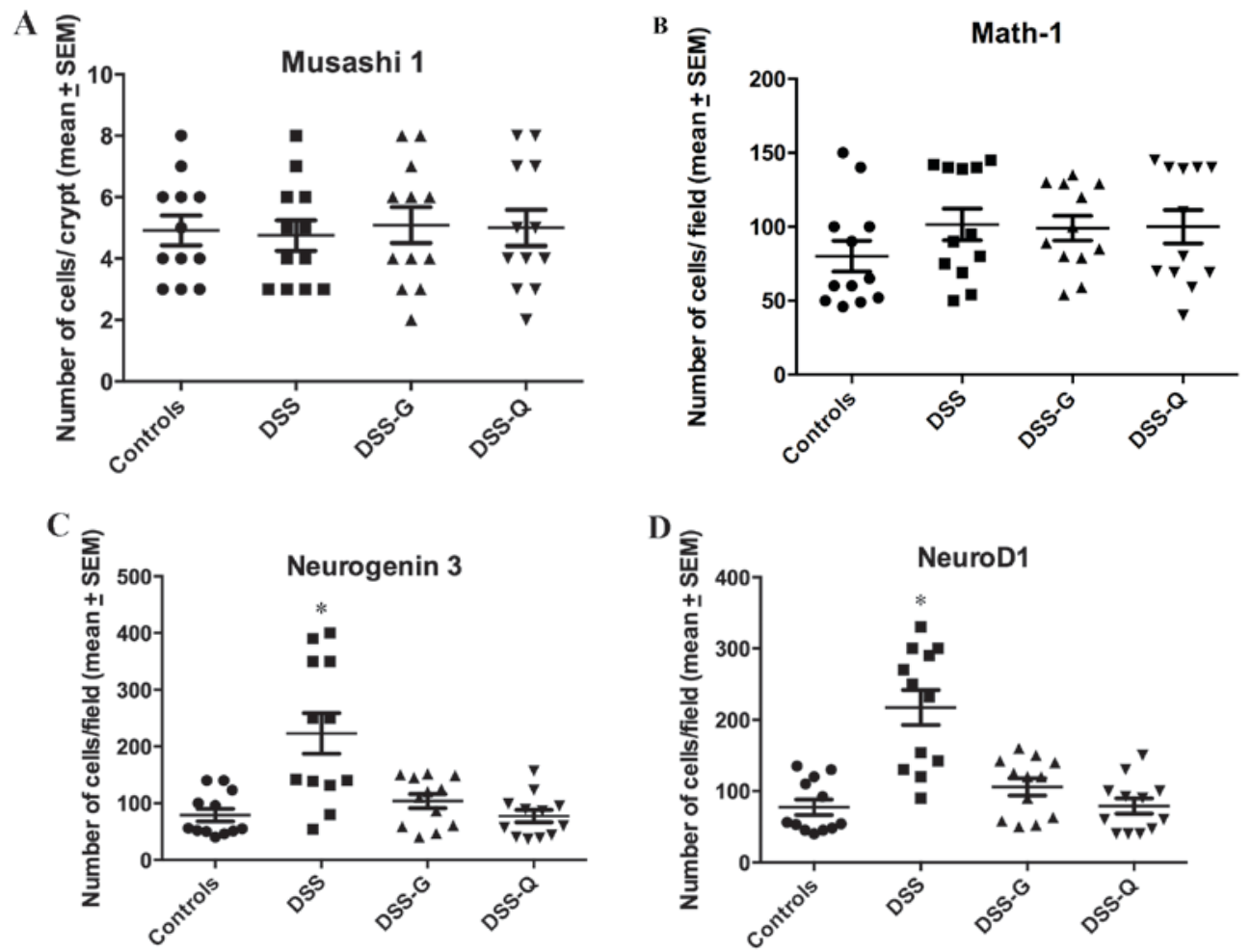

Figure 4. Densities of (A) Msi1-, (B) Math-1, (C) Neurog3- (D) and NeuroD1-immunoreactive cells in the control, DSS, DSS-G and DSS-Q groups. "P<0.001. DSS, dextran sulfate sodium-induced colitis vehicle-treated group; DSS-G, 3-[(dodecylthiocarbonyl)-methyl]-glutarimide-treated DSS group; DSS-Q, dehydroxymethylepoxyquinomicin-treated DSS group; Msi1, Musashi 1; Neurog3, neurogenin 3; NeuroD1, neurogenic differentiation D1.

in the large intestine was significantly elevated in rats with DSS-induced colitis, which is in agreement with previously reported observations (47). DSS-induced colitis is an animal model that is very similar, but not identical, to human UC (58). 

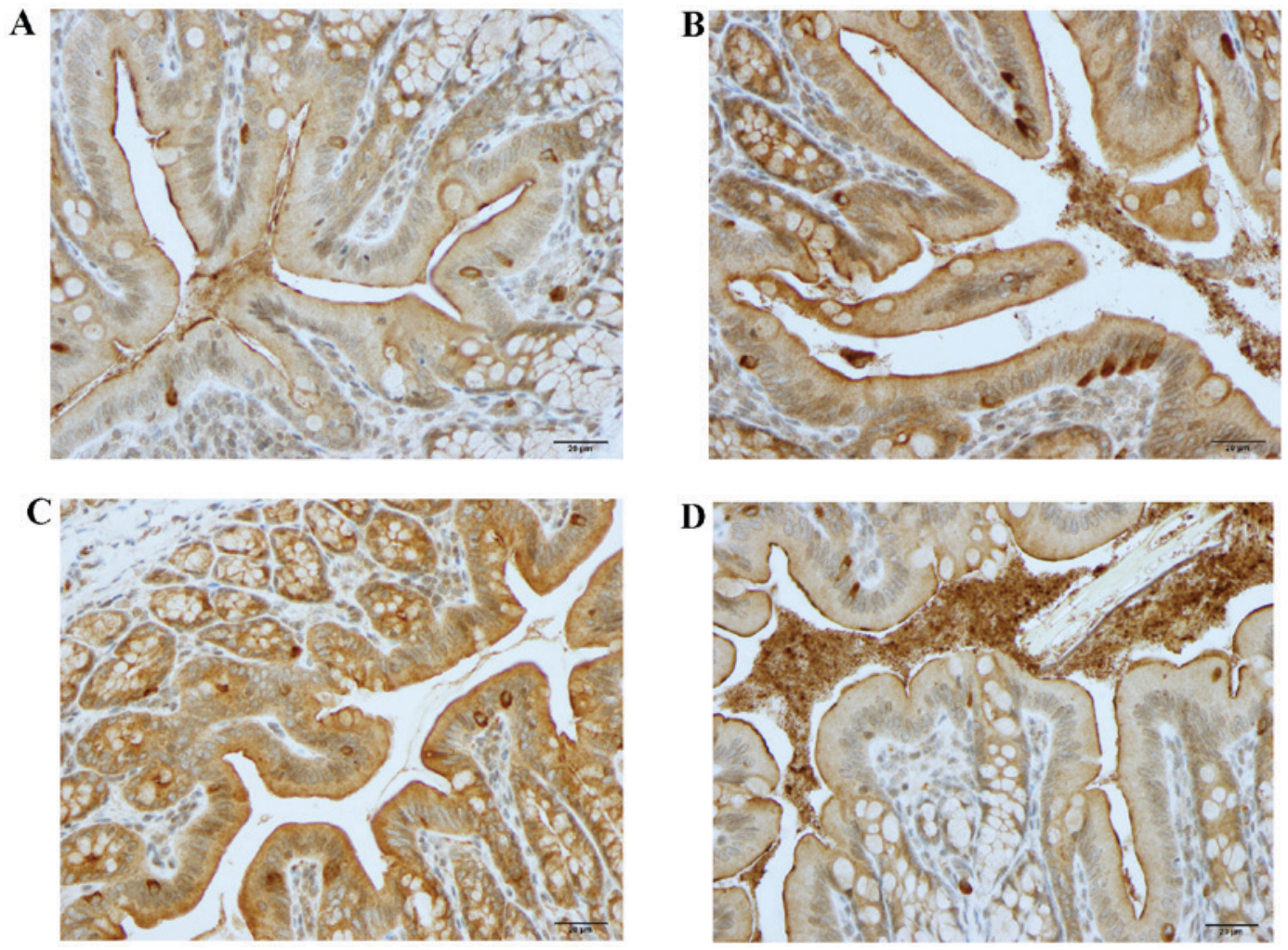

Figure 5. Neurogenin 3-immunoreactive cells in the colon of rats from the (A) control, (B) DSS, (C) DSS-G and (D) DSS-Q groups. DSS, dextran sulfate sodium-induced colitis vehicle-treated group; DSS-G, 3-[(dodecylthiocarbonyl)-methyl]-glutarimide-treated DSS group; DSS-Q, dehydroxymethylepoxyquinomicin-treated DSS group.

The density of CgA-immunoreactive cells in the large intestine has also been reported to be higher in patients with UC compared with in healthy subjects (27).

The intestine contains between 4 and 6 stem cells per crypt, and these cells exhibit two types of activity: i) Dividing into new stem cells (self-renewal, clonogeny) and ii) differentiating into all types of epithelial cell (differentiation) (59-71). The differentiating stem cell progeny includes two lineages: Secretory and absorptive. The secretory lineage gives rise to goblet, endocrine and Paneth cells, whereas the absorptive lineage gives rise to absorptive enterocytes (59-71). Msi1 is a transcription factor expressed by intestinal stem cells and their early progeny (71-74). In the present study, the density of Msi1-immunoreactive cells did not differ between rats in the DSS group and those in the control group, thus indicating that the clonogenic activity of the stem cells was not affected by inflammation.

Math-1 is expressed by an early progenitor in the secretory lineage, and $\mathrm{Math}^{-/}$mice lack secretory cells (75). The present study indicated that the density of Math-1-immunoreactive cells did not significantly differ between rats in the DSS group and those in the control group. These findings suggested that inflammation does not interfere with early secretory lineage differentiation.

Neurog3 is expressed in endocrine progenitor cells, which direct the differentiation of secretory progenitors into endocrine cells (46). Neurog $3^{-/}$mice possess normal densities of goblet and Paneth cells; however, they possess no pancreatic endocrine or enteroendocrine cells $(46,76,77)$. NeuroD1 is a transcription factor that is expressed by cells derived from Neurog3 progenitors $(78,79)$. Mice deficient in NeuroD1 do not possess a subgroup of enteroendocrine cells $(46,80)$. In the present study, the densities of Neurog3- and NeuroD1-immunoreactive cells were higher in DSS-induced rats compared with in control rats. Furthermore, this elevation was strongly correlated with the increased CgA-immunoreactive cell density. This finding provided evidence to suggest that the increased density of enteroendocrine cells observed following DSS-induced colitis may be caused by an increase in the differentiation of early enteroendocrine progenitors during the secretory lineage. Intestinal stem cell proliferation is regulated by numerous signaling pathways (71). It is probable that the DSS-induced inflammatory processes trigger certain signaling pathways, which control the differentiation of the stem-cell secretory lineage into mature enteroendocrine cells.

The present study confirmed the findings of previous studies, that DTCM-G and DHME exhibit potent anti-inflammatory activity in animal models of UC $(48,49)$. Stem cells differentiate rapidly into mature intestinal cells; this process typically takes 2-3 days (72). This may explain why, in the present study, treating rats with DSS-induced colitis with the anti-inflammatory agents DTCM-G and DHME for only 5 days restored the densities of CgA, Neurog3- and NeuroD1-immunoreactive cells to those of the control group. The rapid proliferation and differentiation of epithelial cells are disturbed by inflammation, which causes impairment in epithelial barrier function (81-84). Polyphenols, which is quite different from DTCM-G and DHME, exert a protective effect on epithelial cells and consequently suppress the inflammatory response (81-83). 
In conclusion, the present study demonstrated that the elevated densities of enteroendocrine cells detected in DSS-induced colitis are probably due to increased differentiation of early enteroendocrine progenitors during the secretory lineage. It is likely that inflammatory processes trigger certain signaling pathways that control differentiation of the stem-cell secretory lineage into mature enteroendocrine cells. In addition, this process appears to be responsive to short-term anti-inflammatory treatment. It is probable that stem cell transplantation may be an effective treatment for patients with IBD, that have not responded to current available treatment.

\section{Acknowledgements}

The present study was supported by grants from Helse-Fonna (grant no. 40415) and Helse-Vest (grant no. 911978), Norway.

\section{References}

1. Prantera $\mathrm{C}$ and Marconi S: Glucocorticosteroids in the treatment of inflammatory bowel disease and approaches to minimizing systemic activity. Therap Adv Gastroenterol 6: 137-156, 2013.

2. Cosnes J, Gower-Rousseau C, Seksik P and Cortot A: Epidemiology and natural history of inflammatory bowel diseases. Gastroenterology 140: 1785-1794, 2011.

3. Podolsky DK: Inflammatory bowel disease. N Engl J Med 347: 417-429, 2002.

4. Podolsky DK: The current future understanding of inflammatory bowel disease. Best Pract Res Clin Gastroenterol 16: 933-943, 2002.

5. Carter MJ, Lobo AJ and Travis SP; IBD Section, British Society of Gastroenterology: Guidelines for the management of inflammatory bowel disease in adults. Gut 53 Suppl 5: V1-V16, 2004.

6. Danese S and Fiocchi C: Etiopathogenesis of inflammatory bowel diseases. World J Gastroenterol 12: 4807-4812, 2006.

7. Nunes T, Fiorino G, Danese S and Sans M: Familial aggregation in inflammatory bowel disease: Is it genes or environment? World J Gastroenterol 17: 2715-2722, 2011.

8. El-Salhy M, Gundersen D, Hatlebakk JG and Hausken T: Clinical presentation, diagnosis, pathogenesis and treatment options for lymphocytic colitis (Review). Int J Mol Med 32: 263-270, 2013.

9. El-Salhy M, Seim I, Chopin L, Gundersen D, Hatlebakk JG and Hausken T: Irritable bowel syndrome: The role of gut neuroendocrine peptides. Front Biosci (Elite Ed) 4: 2783-2800, 2012.

10. El-Salhy M, Gundersen D, Hatlebakk JG and Hausken T: Irritable bowel syndrome: Diagnosis, pathogenesis, and treatment options. Nova Science Publishers, Inc., New York, 2012.

11. El-Salhy M: Irritable bowel syndrome: Diagnosis and pathogenesis. World J Gastroenterol 18: 5151-5163, 2012.

12. El-Salhy M, Ostgaard H, Gundersen D, Hatlebakk JG and Hausken T: The role of diet in the pathogenesis and management of irritable bowel syndrome (Review). Int J Mol Med 29: 723-731, 2012.

13. Mawe GM, Coates MD and Moses PL: Review article: Intestinal serotonin signalling in irritable bowel syndrome. Aliment Pharmacol Ther 23: 1067-1076, 2006.

14. Wade PR, Chen J, Jaffe B, Kassem IS, Blakely RD and Gershon MD: Localization and function of a 5-HT transporter in crypt epithelia of the gastrointestinal tract. J Neurosci 16: 2352-2364, 1996.

15. Gershon MD and Tack J: The serotonin signaling system: From basic understanding to drug development for functional GI disorders. Gastroenterology 132: 397-414, 2007.

16. Gershon MD: 5-Hydroxytryptamine (serotonin) in the gastrointestinal tract. Curr Opin Endocrinol Diabetes Obes 20: 14-21, 2013.

17. Gershon MD: Serotonin is a sword and a shield of the bowel: Serotonin plays offense and defense. Trans Am Clin Climato Assoc 123: 268-280, 2012.

18. El-Salhy M, Mazzawi T, Gundersen D, Hatlebakk JG and Hausken T: The role of peptide YY in gastrointestinal diseases and disorders (review). Int J Mol Med 31: 275-282, 2013.
19. Dubrasquet M, Bataille D and Gespach C: Oxyntomodulin (glucagon-37 or bioactive enteroglucagon): A potent inhibitor of pentagastrin-stimulated acid secretion in rats. Biosci Rep 2: 391-395, 1982.

20. Schjoldager B, Mortensen PE, Myhre J, Christiansen J and Holst JJ: Oxyntomodulin from distal gut. Role in regulation of gastric and pancreatic functions. Dig Dis Sci 34: 1411-1419, 1989.

21. Schjoldager BT, Baldissera FG, Mortensen PE, Holst JJ and Christiansen J: Oxyntomodulin: A potential hormone from the distal gut. Pharmacokinetics and effects on gastric acid and insulin secretion in man. Eur J Clin Invest 18: 499-503, 1988.

22. Dakin CL, Small CJ, Batterham RL, Neary NM, Cohen MA, Patterson M, Ghatei MA and Bloom SR: Peripheral oxyntomodulin reduces food intake and body weight gain in rats. Endocrinology 145: 2687-2695, 2004.

23. Wynne K, Park AJ, Small CJ, Patterson M, Ellis SM, Murphy KG, Wren AM, Frost GS, Meeran K, Ghatei MA and Bloom SR: Subcutaneous oxyntomodulin reduces body weight in overweight and obese subjects: A double-blind, randomized, controlled trial. Diabetes 54: 2390-2395, 2005.

24. El-Salhy M and Hausken T: The role of the neuropeptide $Y$ (NPY) family in the pathophysiology of inflammatory bowel disease (IBD). Neuropeptides 55: 134-144, 2016.

25. Camilleri M: Peripheral mechanisms in irritable bowel syndrome. N Engl J Med 367: 1626-1635, 2012.

26. Jianu CS, Fossmark R, Syversen U, Hauso $\varnothing$ and Waldum HL: A meal test improves the specificity of chromogranin A as a marker of neuroendocrine neoplasia. Tumour Biol 31: 373-380, 2010.

27. El-Salhy M, Danielsson A, Stenling R and Grimelius L: Colonic endocrine cells in inflammatory bowel disease. J Intern Med 242: 413-419, 1997.

28. El-Salhy M, Gundersen D, Hatlebakk JG and Hausken T: Chromogranin a cell density as a diagnostic marker for lymphocytic colitis. Dig Dis Sci 57: 3154-3159, 2012.

29. El-Salhy M, Gundersen D, Hatlebakk JG and Hausken T: High densities of serotonin and peptide YY cells in the colon of patients with lymphocytic colitis. World J Gastroenterol 18: 6070-6075, 2012

30. El-Salhy M, Lomholt-Beck B and Gundersen TD: High chromogranin A cell density in the colon of patients with lymphocytic colitis. Mol Med Rep 4: 603-605, 2011.

31. Moran GW, Pennock J and McLaughlin JT: Enteroendocrine cells in terminal ileal Crohn's disease. J Crohns Colitis 6: 871-880, 2012.

32. Besterman HS, Mallinson CN, Modigliani R, Christofides ND, Pera A, Ponti V, Sarson DL and Bloom SR: Gut hormones in inflammatory bowel disease. Scand J Gastroenterol 18: 845-852, 1983.

33. El-Salhy M, Suhr O and Danielsson A: Peptide YY in gastrointestinal disorders. Peptides 23: 397-402, 2002.

34. Tari A, Teshima H, Sumii K, Haruma K, Ohgoshi H, Yoshihara M, Kajiyama G and Miyachi Y: Peptide YY abnormalities in patients with ulcerative colitis. Jpn J Med 27: 49-55, 1988.

35. Sciola V, Massironi S, Conte D, Caprioli F, Ferrero S, Ciafardini C, Peracchi M, Bardella MT and Piodi L: Plasma chromogranin a in patients with inflammatory bowel disease. Inflamm Bowel Dis 15: 867-871, 2009.

36. Bishop AE, Pietroletti R, Taat CW, Brummelkamp WH and Polak JM: Increased populations of endocrine cells in Crohn's ileitis. Virchows Arch A Pathol Anat Histopathol 410: 391-396, 1987.

37. Manocha M and Khan WI: Serotonin and GI disorders: An update on clinical and experimental studies. Clin Transl Gastroenterol 3: e13, 2012.

38. Stoyanova II and Gulubova MV: Mast cells and inflammatory mediators in chronic ulcerative colitis. Acta Histochem 104: 185-192, 2002.

39. Yamamoto H, Morise K, Kusugami K, Furusawa A, Konagaya T, Nishio Y, Kaneko H, Uchida K, Nagai H, Mitsuma T and Nagura H: Abnormal neuropeptide concentration in rectal mucosa of patients with inflammatory bowel disease. J Gastroenterol 31: 525-532, 1996.

40. Payer J, Huorka M, Duris I, Mikulecky M, Kratochvílová H, Ondrejka P and Lukác L: Plasma somatostatin levels in ulcerative colitis. Hepatogastroenterology 41: 552-553, 1994.

41. Watanabe T, Kubota Y, Sawada T and Muto T: Distribution and quantification of somatostatin in inflammatory disease. Dis Colon Rectum 35: 488-494, 1992.

42. Koch TR, Carney JA, Morris VA and Go VL: Somatostatin in the idiopathic inflammatory bowel diseases. Dis Colon Rectum 31: 198-203, 1988 
43. Khan WI and Ghia JE: Gut hormones: Emerging role in immune activation and inflammation. Clin Exp Immunol 161: 19-27, 2010.

44. Margolis KG and Gershon MD: Neuropeptides and inflammatory bowel disease. Curr Opin Gastroenterol 25: 503-511, 2009.

45. Bampton PA and Dinning PG: High resolution colonic manometry-what have we learnt?-A review of the literature 2012. Curr Gastroenterol Rep 15: 328, 2013.

46. Wang J, Cortina G, Wu SV, Tran R, Cho JH, Tsai MJ, Bailey TJ, Jamrich M, Ament ME, Treem WR, et al: Mutant neurogenin-3 in congenital malabsorptive diarrhea. N Engl J Med 355: 270-280, 2006.

47. El-Salhy M and Umezawa K: Treatment with novel AP-1 and $\mathrm{NF}-\kappa \mathrm{B}$ inhibitors restores the colonic endocrine cells to normal levels in rats with DSS-induced colitis. Int J Mol Med 37: 556-564, 2016

48. Funakoshi T, Yamashita K, Ichikawa N, Fukai M, Suzuki T, Goto R, Oura T, Kobayashi N, Katsurada T, Ichihara S, et al: A novel NF-kappaB inhibitor, dehydroxymethylepoxyquinomicin, ameliorates inflammatory colonic injury in mice. J Crohns Colitis 6: 215-225, 2012.

49. El-Salhy M, Umezawa K, Gilja OH, Hatlebakk JG, Gundersen D and Hausken T: Amelioration of severe TNBS induced colitis by novel AP-1 and NF- $\kappa$ B inhibitors in rats. Scientific World Journal 2014: 813804, 2014.

50. Grimstad T, Bjørndal B, Cacabelos D, Aasprong OG, Omdal R, Svardal A, Bohov P, Pamplona R, Portero-Otin M, Berge RK and Hausken T: A salmon peptide diet alleviates experimental colitis as compared with fish oil. J Nutr Sci 2: e2, 2013.

51. Stucchi AF, Shofer S, Leeman S, Materne O, Beer E, McClung J, Shebani K, Moore F, O'Brien M and Becker JM: NK-1 antagonist reduces colonic inflammation and oxidative stress in dextran sulfate-induced colitis in rats. Am J Physiol Gastrointest Liver Physiol 279: G1298-G1306, 2000.

52. Ota E, Takeiri M, Tachibana M, Ishikawa Y, Umezawa K and Nishiyama S: Synthesis and biological evaluation of molecular probes based on the 9-methylstreptimidone derivative DTCM-glutarimide. Bioorg Med Chem Lett 22: 164-167, 2012.

53. Takeiri M, Tachibana M, Kaneda A, Ito A, Ishikawa Y, Nishiyama S, Goto R, Yamashita K, Shibasaki S, Hirokata G, et al: Inhibition of macrophage activation and suppression of graft rejection by DTCM-glutarimide, a novel piperidine derived from the antibiotic 9-methylstreptimidone. Inflamm Res 60: 879-888, 2011.

54. Ishikawa Y, Tachibana M, Matsui C, Obata R, Umezawa K and Nishiyama S: Synthesis and biological evaluation on novel analogs of 9-methylstreptimidone, an inhibitor of NF-kappaB Bioorg Med Chem Lett 19: 1726-1728, 2009.

55. Umezawa N, Matsumoto N, Iwama S, Kato N and Higuchi $\mathrm{T}$ : Facile synthesis of peptide-porphyrin conjugates: Towards artificial catalase. Bioorg Med Chem 18: 6340-6350, 2010.

56. el-Salhy M, Sandstrom O, Näsström E, Mustajbasic M and Zachrisson S: Application of computer image analysis in endocrine cell quantification. Histochem J 29: 249-256, 1997.

57. El-Salhy M, Gilja OH, Gundersen D, Hatlebakk JG and Hausken T: Duodenal chromogranin a cell density as a biomarker for the diagnosis of irritable bowel syndrome. Gastroenterol Res Pract 2014: 462856, 2014

58. Elson CO, Sartor RB, Tennyson GS and Riddell RH: Experimental models of inflammatory bowel disease. Gastroenterology 109: $1344-1367,1995$

59. Cardoso WV and Lü J: Regulation of early lung morphogenesis: Questions, facts and controversies. Development 133: 1611-1624, 2006.

60. Darlington GJ: Molecular mechanisms of liver development and differentiation. Curr Opin Cell Biol 11: 678-682, 1999.

61. Fausto N, Campbell JS and Riehle KJ: Liver regeneration. Hepatology 43 (2 Suppl 1): S45-S53, 2006.

62. Rawlins EL and Hogan BL: Ciliated epithelial cell lifespan in the mouse trachea and lung. Am J Physiol Lung Cell Mol Physiol 295: L231-L234, 2008.

63. Zaret KS: Regulatory phases of early liver development: Paradigms of organogenesis. Nat Rev Genet 3: 499-512, 2002.

64. Barker N, van Es JH, Kuipers J, Kujala P, van den Born M, Cozijnsen M, Haegebarth A, Korving J, Begthel H, Peters PJ and Clevers $\mathrm{H}$ : Identification of stem cells in small intestine and colon by marker gene Lgr5. Nature 449: 1003-1007, 2007.
65. Barker N, van de Wetering $\mathrm{M}$ and Clevers $\mathrm{H}$ : The intestinal stem cell. Genes Dev 22: 1856-1864, 2008.

66. Cheng $\mathrm{H}$ and Leblond CP: Origin, differentiation and renewal of the four main epithelial cell types in the mouse small intestine. V. Unitarian theory of the origin of the four epithelial cell types. Am J Anat 141: 537-561, 1974.

67. Le Douarin NM and Teillet MA: The migration of neural crest cells to the wall of the digestive tract in avian embryo. J Embryol Exp Morphol 30: 31-48, 1973.

68. Rawdon BB and Andrew A: Origin and differentiation of gut endocrine cells. Histol Histopathol 8: 567-580, 1993.

69. Hoffman J, Kuhnert F, Davis CR and Kuo CJ: Wnts as essential growth factors for the adult small intestine and colon. Cell Cycle 3: 554-557, 2004

70. Korinek V, Barker N, Moerer P, van Donselaar E, Huls G, Peters PJ and Clevers H: Depletion of epithelial stem-cell compartments in the small intestine of mice lacking Tcf-4. Nat Genet 19: 379-383, 1998.

71. Montgomery RK and Breault DT: Small intestinal stem cell markers. J Anat 213: 52-58, 2008.

72. Potten CS, Booth C, Tudor GL, Booth D, Brady G, Hurley P, Ashton G, Clarke R, Sakakibara S and Okano H: Identification of a putative intestinal stem cell and early lineage marker; musashi-1. Differentiation 71: 28-41, 2003.

73. Kayahara T, Sawada M, Takaishi S, Fukui H, Seno H, Fukuzawa H, Suzuki K, Hiai H, Kageyama R, Okano H and Chiba T: Candidate markers for stem and early progenitor cells, Musashi-1 and Hes1, are expressed in crypt base columnar cells of mouse small intestine. FEBS Lett 535: 131-135, 2003.

74. He XC, Yin T, Grindley JC, Tian Q, Sato T, Tao WA, Dirisina R, Porter-Westpfahl KS, Hembree M, Johnson T, et al: PTEN-deficient intestinal stem cells initiate intestinal polyposis. Nat Genet 39: 189-198, 2007.

75. Yang Q, Bermingham NA, Finegold MJ and Zoghbi HY: Requirement of Math1 for secretory cell lineage commitment in the mouse intestine. Science 294: 2155-2158, 2001.

76. Jenny M, Uhl C, Roche C, Duluc I, Guillermin V, Guillemot F, Jensen J, Kedinger M and Gradwohl G: Neurogenin3 is differentially required for endocrine cell fate specification in the intestinal and gastric epithelium. EMBO J 21: 6338-6347, 2002.

77. Lee CS, Perreault N, Brestelli JE and Kaestner KH: Neurogenin 3 is essential for the proper specification of gastric enteroendocrine cells and the maintenance of gastric epithelial cell identity. Genes Dev 16: 1488-1497, 2002.

78. Naya FJ, Huang HP, Qiu Y, Mutoh H, DeMayo FJ, Leiter AB and Tsai MJ: Diabetes, defective pancreatic morphogenesis and abnormal enteroendocrine differentiation in BETA2/neuroDdeficient mice. Genes Dev 11: 2323-2334, 1997.

79. Ahlgren U, Jonsson $\mathrm{J}$ and Edlund $\mathrm{H}$ : The morphogenesis of the pancreatic mesenchyme is uncoupled from that of the pancreatic epithelium in IPF1/PDX1-deficient mice. Development 122: 1409-1416, 1996.

80. Schonhoff SE, Giel-Moloney M and Leiter AB: Minireview: Development and differentiation of gut endocrine cells. Endocrinology 145: 2639-2644, 2004.

81. Yang G, Bibi S, Du M, Suzuki T and Zhu MJ: Regulation of the intestinal tight junction by natural polyphenols: A mechanistic perspective. Crit Rev Food Sci Nutr : Mar 23, 2016 (Epub ahead of print)

82. Yang G, Wang $\mathrm{H}$, Kang $\mathrm{Y}$ and Zhu MJ: Grape seed extract improves epithelial structure and suppresses inflammation in ileum of IL-10-deficient mice. Food Funct 5: 2558-2563, 2014.

83. Yang G, Xue Y, Zhang H, Du M and Zhu MJ: Favourable effects of grape seed extract on intestinal epithelial differentiation and barrier function in IL10-deficient mice. Br J Nutr 114: 15-23, 2015.

84. Yang GB and Lackner AA: Proximity between 5-HT secreting enteroendocrine cells and lymphocytes in the gut mucosa of rhesus macaques (Macaca mulatta) is suggestive of a role for enterochromaffin cell 5 -HT in mucosal immunity. J Neuroimmunol 146: 46-49, 2004. 